\title{
A Critical Analysis of Radical Feminism in Jaishankar Prasad's Play Dhruvsvamini
}

\author{
P.V.S. Chandrasekara \\ Centre for International Affairs, University of Kelaniya, Sri Lanka \\ sashinivithana@gmail.com
}

\begin{abstract}
The aim of this paper is to examine how Radical Feminism was discussed in Hindi plays in early 1930s, when it was not even introduced as a concept to literature. Jaishankar Prasad is an Indian writer who wrote the play Dhruvsvamini to introduce Radical Feminism to the Indian orthodox society. He started a rational discussion on radical issues such as; domestic oppression, polygamy, sexuality, right for the divorce, remarriage through this play. This paper reiterates that, though the concept of Radical Feminism came into the western literature around 1960s, the nucleus of radical thoughts can be identified in Prasad's plays of early twentieth century. This paper emphasizes that he has been influenced by Buddhism and the thoughts of Indian feminist activists of that time. Literature review has been conducted to analyze the play Dhruvsvamini. The outcome of this paper would be an exploration of the Radical Feminism discussed in Hindi drama.
\end{abstract}

Key words: Radical Feminism, Hindi play, Polygamy, Patriarchy, Domestic oppression

\section{Introduction}

The play Dhruvsvamini which is based on a historical story related to the Gupta period was written by Jaishankar Prasad in the year 1933. Prasad (1890-1937) who was born in Kashi belongs to the Romantic period of Hindi literature. Vajpai (2013) mentions that his plays not only highlight reality or historical stories but they also consists of cultural values of the society. Another scholar Rastogi (2008) states that although the Dhruvsvamini is based on a historical story it indicates the reality of the life and therefore, this play is different from other plays of the same period. Though Prasad belongs to the Romantic Period of Hindi literature (1920-1936) he wrote this play in order to indicate the reality of the Indian society.

Feminism was started as a concept in western literature and later on it came into the Indian literature. Theory of feminism can be divided into two waves: first and second wave where the concept of radical feminism which addresses the liberation of women belongs to the second wave feminism dating from 1960 to the present day. The current paper examines whether Prasad implemented radical feminism while writing the play Dhruvsvamini which was not even introduced as a concept to the literature in early 1930s. Jaishankar Prasad's play Dhruvsvamini has been implemented as the primary resource for the current study, whereas, books, mag- azines, and journals related to Hindi drama, Buddhism, and feminism have been used as secondary resources. A literature review has been employed to analyze this play under the theme of Radical Feminism. The aim of this study is to examine radical feminism in Hindi drama in early 1930s.

\section{Theoretical Framework}

Feminism arrived as a movement in America and England in the Victorian era. Women were not considered as full citizens in England and they did not have the same political rights as men. They were prohibited and not even allowed to own property at that time. As a result of all these issues first wave feminism emerged during 1850s.

In the late 1960s a new women's movement known as 'radical feminism' became popular. Radical feminists raised their voice against domestic violence and they demanded their own identity in patriarchal society. Bryson \& Campling (1999) mentions that "in the late 1960s, however, they become an important strand of the new women's movement known as 'radical feminism' because, its proponents claimed, it went to the roots of women's oppression". According to this statement the new conception radical feminism came as a result of maltreatment of women. Singh (2007) further explains radical feminism and states that "it explores gender-role stereotyping, women's oppressed position in the family and workplace, the political sig- 
nificance of lesbianism and critiques of male violence in terms of power (rape, battery, pornography, etc.)". She identifies this theory in a broader view and mentions the inequality in family and workplace.

India is a male dominated country which was widely characterized by child marriage, and prohibition of widow remarriage was common in Prasad era. Although the concept of feminism is not there in the Indian society many scholars started to raise their voice against this inequality of women. Raja Rammoham Ray, Pandit Ishwar Chandra Vidyasagar (1820-1891) are the pioneers in the agitation for women's rights in India. 'Young Bengali Movement' which gave special attention to the remarriage of widows was founded in India to introduce radical changes to the society in 1830. Ishwar Chandra Vidyasagar (1820-1891) and Dayanada Saraswati (1824-1883) are the social activists who worked against prohibition of widow remarriage and other evils affecting women. Jayawardena (2009) mentioned that as a result of their hard work remarriage of widows was legally permitted through the Act of 1856. However, it was not strong enough to change the orthodox beliefs regarding widows in Indian society. Vidyasagar can be introduced as a feminist who campaigned against polygamy which was practiced by both high caste Hindus and Muslims. Prasad is inspired with these thoughts when he wrote the play Dhruvswamini.

The Feminist Movement in India was quite different from western thinkers since, male feminists were the pioneers of the agitation for women's rights in India. With the influence of this trend female feminists such as Pandita Ramabai (18581922), Sarojani Naidu (1879-1949) and Kamaladevi Chatttopadhyaya also started to fight for their rights. Though the concept of Radical Feminism came into the western literature about late 1960s, such thoughts were there in early Indian movement.

Radical changes regarding women were introduced to the Indian society thousands years before by Lord Buddha. Five years after the enlightenment of Lord Buddha his foster mother, Prajapathi accompanied by five hundred women and came to Buddha to get permission to become nuns. Though they asked permission three times Lord Buddha did not accept it. At the end they cut off their hair and came with saffron cloths all the same. At that time Ananda thero asked for permission from Buddha on behalf of them. It is explained in Chullavagga (as cited in [Gross, 1993]) in her work Buddhism of the patriarchy as follows:

Then Ananda, according to the text (cullavagga, x 1.3), approached the Buddha with other arrangement, asking, "Lord, are women, having gone forth from home into homelessness in the dhamma and discipline proclaimed by the Truth-finder, able to realize the fruit of stream- attainment or the fruit of once- retuning or the fruit of nonretuning or perfection?"

It reiterates how much she was dedicated to establish the Bhikshunihood ${ }^{1}$ and she is the first lady who fought for radical changes in society. In away Prajapathi's action contains the nucleus of radical feminism during the Lord Buddha's time. Buddha gave permission for Bhikshunihood as well as introduced radical changes to the Indian society by giving his kind attention to women who were neglected by the society, such as; Patachara and Rajjumala. With this argument it is clear that the concept of radical changes came into the society in Lord Buddha's period.

All the previously mentioned theories and concepts discuss the evolution of radical feminism in both western and Indian perceptions. The current paper discusses to what extent they have been implemented in the play Druvsvamini by Jaishankar Prasad. In order to identify the radical aspects of this play it has been textually analyzed with above mentioned concepts.

\section{Methods and Literature Review}

A myriad of scholars have worked on Jaishankar Prasad and his dramas. Some of the main scholars who worked on his dramas are: Rastogi (2008), Vajpai (2013), Sharma (2017), Pota (1987). Among these studies Pota (1987) criticized the play Dhruvsvamini as follows:

Prasad was convinced of the need for the emancipation of woman. At national sense, Gandhi and a number of other modernist gave a call to the woman to cast off their old beliefs, superstitions, and participate in the freedom movement. Prasad did not consider

\footnotetext{
${ }^{1}$ Bhikshunihood Females ordained as Buddhist monks in accordance with rules and disciplines of Dhamma
} 
woman as a dumb-driven cattle to be moved by the decisions of the man. The practice of not divorcing the husband in the higher strata and high castes Hindus was not acceptable to the author.

Pota (1987) emphasized the importance of the emancipation of women from their unsatisfied married life, which was not allowed at that time. She identified Prasad's revolutionary ideas and said Prasad did not accept that women should always keep under the guidance of men. As a matter of fact, through rejecting patriarchy and granting permission to the divorce Prasad tried to bring radical changes to the society.

Narayana \& Nagendra (1981) discussed about Dhruvsvamini in detail and stated that "So far the kings and queens were painted with usual colors. For the first time the author moves towards a deeper probe between the relations of a husband and wife. Dhruvsvamini is the wife of an ineffective and effeminate king. She is attracted to her brother-in-law who has all the manly qualities."

With the above statement Narayana \& Nagendra (1981) accepted that the author started discussing profound matters between married couples. According to him Dhruvsvamini's attraction towards Chandragupt was not an offence but it is due to human nature.

Nagendra \& Hardayal (2009), Rastogi (2008), and Sharma (2017) described Dhruvsvamini as a problem centered play. Rastogi (2008) further identified the problems discussed in the play as; issues related to feminine personality, women's rights and independence, oppression in the male society and separation from an ineffective husband.

All of the previously mentioned studies indicate the Dhruvsvamini as a play which discuss the issues related to feminism. However, current paper is significant in understanding the radical feminist aspects in the play Dhruvsvamini.

\section{Discussion}

\section{Domestic Oppression and Radical Femi- nism in Dhruvsvamini}

The conception of radical feminism was introduced in order to safeguard women from domestic violence and oppression. Prasad raised his voice against domestic abuse of women in Indian society through the characters of Dhruvsvamini and
Koma. The play begins with a discussion between Dhruvsvamini and her servant, who is the lady spy of her husband. Kadgadarini, the servant even does not like to talk to queen Dhruvsvamini because she is not allowed to do so. The short conversation between them at the beginning of the play highlights that how Dhruvsvamini is being treated as a slave in her own place. However, the author challenged the exploitation of women and portrayed Dhruvsvamini as a character who is challenging her husband's decisions about her. Prasad (n.d.) introduced these radical changes to the readers through the dialogue of Dhruvsvamini:

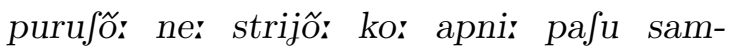
patti samad $3^{h}$ kər un pər atjastfarr karne: ka: ab jais bana: lija: he: vo: me:re: sa:th nahîi tjal sakta:. jədi tum merri rakja: nahĩ kər sakter, apne: kul kir marja:da:, na:ri: ka: go:rəv nahĩi batfa: sakte:, to: $\operatorname{mud}^{h}$ e: be: $t \int b^{h}$ i: nahî: səkte: ho:

\section{(Men always consider women as a property of their own and misuse them. But don't even think to do those things with me.)}

Through this dialogue Prasad tries to grant liberation to women from the traditional bonds of marriage. Dhruvsvamini raises her voice against domestic violence and demands her own identity as a queen and as well as a married women from her husband Ramgupta, which are the aspects of radical feminism. Prasad highlighted the importance of the mutual understanding of husband and wife, which is hardly discussed in Indian society. When Dhruvsvamini is not getting love and protection from her husband, she remembers that she is strong enough to protect herself, which is a radical thought to the Indian patriarchal society.

The ideal married lady in Indian society does not even have the right to think about another person besides her husband and he is considered as a god to his wife. There was an attraction between Dhruvsvamini and Chandragupta, brother of her husband. However, according to the instructions of her father, Dhruvsvamini had to get married with Ramgupta. When she is bored with her marriage, she does not hesitates to express her feelings towards Chandragupta with her servant. Prasad (n.d.) expressed women's feelings through her dialogue: "kitna: anub $b^{h}$ ustipurrno $t^{h}$ a: vo: e:k 


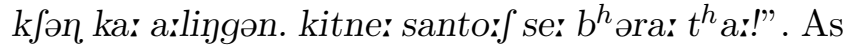
a male writer Prasad successfully conveys women's psychology, specially their deeper feelings regarding their marriage. Prasad emphasizes that human feelings cannot be controlled by rules, which also comes under violence against women. He tries to introduce radical ideas regarding feminism to the Indian society, which is highly believed in patriarchal domain of men.

\section{Polygamy and Radical Feminism in Dhruvsvamini}

Polygamy is another issue which caused women's oppression and was practiced by both Hindus and Muslims in India. Under this law women were treated as sexual objects which can be used at any time. Ishwar Chandra Vidyasagar (1820-1891) is the famous Indian feminist who worked against polygamy. Jayawardena (2009) emphasizes the issues of polygamy in Indian society as follows:

The issue of polygamy was first raised by Hindu reformers who campaigned for its abolition and by Bengali playwrights and writers who satirized the practice; in the 1850s, many petitions against polygamy were presented to the government, one being from the Maharaja of Burdwan in 1855. The campaign was continued, especially by Vidyasagar who, in the 1870s, wrote tracts exposing the evils of polygamy.

Social activists of the Indian feminist movement were completely against polygamy since 19th century. It gives a clear evidence that radical feminism was not a novel concept to Indian feminist movement. Prasad may be highly inspired with early famine activists such as Vidyasagar and as a result of that he tries to introduce radical thoughts against polygamy through his play Dhruvsvamini.

According to the author the reason for the unexpected death of King Shakraj was his extreme desire for polygamy. Shakraj sends a message to Ramgupta that if he sends Dhruvsvamini as a gift to Shakraj he will not conquer their land. Shakraj not only demands Dhruvsvamini and also he demands all the wives of ministers in Gupta emperor to his ministers. He kept Kma as his illegal wife on one side and demanded for Dhruvsvamini as his wife. Prasad emphasized that women were treated as the property of men in Gupta period. Prasad who is completely against the concept of polygamy, highlights the bad effects of polygamy through the miserable death of Shakraj.

\section{Buddhist Philosophy and Radical Femi- nism in Dhruvsvamini}

Dhruvsvamini is a play which discuss women's rights of medieval period of India. The writers of that period is influenced with Hinduism and Buddhism. Women were always treated as second citizens under the patriarchal laws of Hinduism. The Manu Smriti or Laws of Manu is the best example for women's position under Hinduism. It describes women as follows:

174. Her father protects [her] in childhood, her husband protects [her] in youth, and her sons protect [her] in old age; a woman is never to be left unprotected 9:3.

[Acharya, 2009]

A woman is treated as a human being who is always dependent on men. In this scene Lord Buddha may be the first great personality who gave an identity to women through granting permission to Bhikshunihood. Although Hinduism discuss about women and their rights in this way Prasad never accepts it and challenged these thoughts through this play. Chobey (2009) discusses about the verses of wise nuns and emphasized that "Buddhism and feminism can be seen as particularly linked with each other. Both are concerned with emancipation, with broadening our self-view which would otherwise remain restricted."

Though radical feminists in late 1960s demanded their own identity, Lord Buddha gave a unique identity to women by establishing Bhikshunihood in Buddhism. This historical play of Prasad based on Gupta period which was mainly based on Hinduism and partly influenced by Buddhism. Because of that he may have used Buddhist philosophy while introducing radical feminist thoughts through the play Dhruvsvamini.

Lord Buddha criticized polygamy which was widely practiced by high class nobles. According to Parabhava Sutta the person who is not satisfied with his wife and go to others will be declined.

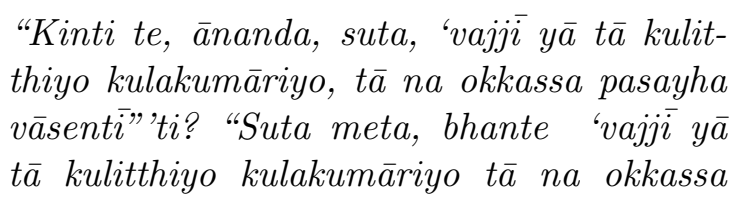


pasayha vāsentī"'ti. "Yāvakīvañca, ānanda, vajji $\bar{i} \bar{a}$ tā kulitthiyo kulakumāriyo, tā na okkassa pasayha vāsessanti, vuddhiyeva, ānanda, vajjīna pāikanikhā, no parihani.

[Mahaparinibba Sutta, n.d., Sutta Central, n.d.]

Prasad is highly influenced with Buddhist concepts and emphasizes how Shakraj is being destroyed because of his extreme desire for sex. Therigatha; the significant verses written by wise nuns also encourage women's emancipation from male dominated society. With the influence of all above mentioned Buddhist concepts, Prasad grants permission to Dhruvsvamini to divorce at the end of the play. Through that he introduces radical feminist thoughts to the readers.

\section{Conclusion}

Several significant conclusions can be made from the points discussed in above sections. Firstly, being a writer of the Romantic Period of Hindi literature Prasad successfully introduced radical feminist thoughts to the Indian society through granting permission to divorce in his play Dhruvsvamini. Though remarriage of widows were legally permitted under the Act of 1856, which was not accepted and practiced by Indian society. Through introducing the remarriage of Dhruvsvamini with Chandragupta, Prasad attempted to socialize the above Act and tried to introduce radical changes to the society.

Secondly, although radical feminism recognized as a theory in late 1960s the nucleus of this concept started in Buddhism where Prajapathi; the foster mother of Siddharth claimed for Bhikkunihood from Lord Buddha.

Finally, he criticized polygamy and women's condition under patriarchal dominance which caused to domestic oppression of women with using Buddhist concepts through this play. Therefore, it is clear that Prasad had made a commendable effort to give social recognition for divorcee and widow marriage. As a result of all these things it is noticeable that aspects of radical feminism can be identified in the play Dhruvsvamini.

\section{References}

Acharya, R. R. (2009). The Laws of Manu for the 21st Century. Retrieved March 2018 from http://www.srimatham.com/uploads/5/ $5 / 4 / 9 / \ldots /$ manu_for_modern_times.pdf

Bryson,V. \& Campling, J. (Eds.). (1999). Feminist Debates: Issues of Theory and Political Practice. Hounds mill: Macmillan.

Chobey, A. (2009). Voices from the Yore: Therigatha Writings of the Bhikknis. The Indian Review of world Literature in English. Retrieved March 2018 from http://worldlitonline. net/voices-from-the-yore.pdf

Mahaparinibba Sutta (n.d.). dīgha nikāya 16. Retrieved March 2018 from https://suttacentral. net $/ \mathrm{dn} 16 / \mathrm{pli} / \mathrm{ms}$.

Gross, Rita. M. (1993). Buddhism After Patriarchy: A feminist history, analysis, and reconstruction of Buddhism. USA: State University of New York Press.

Jayawardena, K. (2009). Feminism and Nationalism in the Third World (3rd ed.). Colombo: Social Scientists' Association.

Narayana, B. \& Nagendra. (Ed.). (1981). Hindi drama and Stage. New Delhi: Bansal \& Company.

Nagendra \& Hardayal, (Eds.). (2009). Hindi Sahitya Ka Itihas (35th ed.). Noida: Mayur Paperbeks.

Pota, N. (1987). Content Analysis of Hindi Literature: Preparation of Manual \& Application. Bombay: Himalaya Publishing House.

Prasad, J. (n.d.). Dhruvsvamini. New Delhi: Kamal Prakashan.

Rastogi, G. (2008). Hindi Natak ka Athma Sangharsh. Allahabad-1: Lok Bharati Prakashan.

Sharma, J. P. (2017). Prasad ke Natakon ka Shastriya Adhyayan (2nd ed.). New Delhi: Vani Prakashan.

Singh, C. N. (2007). Only So Far and No Further Radical Feminism and Women's Writing, Atlantic Publishers \& Distributors

Sutta Central: Early Buddhist Texts, Translations and Paralles. (n.d.). Retrieved March 2018 from https://suttacentral.net/dn16/pli/ms.

Vajpai, N. D. (2013). Jayashankar Prasad (1st ed.). Allahabad-1: Lok Bharati Prakashan. 